\title{
Kader Bola Salju : Role Model Penggunaan Obat di Masyarakat
}

\author{
Yosi Febrianti $^{1 *}$, Yulianto ${ }^{1}$, Saepudin ${ }^{1}$, Novyan Lusiana ${ }^{2}$ \\ ${ }^{1}$ Fakultas Matematika dan Ilmu Pengetahuan Alam, Universitas Islam Indonesia \\ ${ }^{2}$ Fakultas Kedokteran, Universitas Islam Indonesia \\ *Corresponding Email: yosi.febrianti@uii.ac.id
}

\begin{abstract}
ABSTRAK
Perilaku pencarian pertolongan kesehatan yang utama atau paling banyak dilakukan jika penduduk sakit adalah melakukan pengobatan mandiri / swa medikasi (self medication) dengan membeli obat di warung, toko swalayan dan apotek. Masyarakat hanya mengandalkan iklan, referensi keluarga, teman, tetangga yang tidak memiliki dasar pendidikan kefarmasian sebagai panduan dalam menggunakan obat. Hal tersebut potensial menimbulkan permasalahan di bidang kesehatan. Metode kegiatan didasarkan pada model promosi kesehatan, melalui pemberian edukasi dan pelatihan kader terpilih tentang penggunaan obat secara rasional. Kegitan ini melibatkan ibu-ibu PKK dusun Candi 3, Desa Sardonoharjo, Sleman. Hasil kegiatan menunjukkan adanya peningkatan pengetahuan ibu-ibu PKK di dusun Candi 3 dan terbentuknya kader bola salju yang akan membantu masyarakat dalam menggunakan obat secara tepat dan rasional.
\end{abstract}

Kata Kunci: Apoteker, Farmasi, Obat, Swamedikasi.

\begin{abstract}
The behavior of seeking health assistance is the main or most widely done if the population is sick is doing self-medication / self-medication by buying medicines at stalls, convenience stores and pharmacies. People only rely on advertisements, family references, friends, neighbors who do not have a basic pharmaceutical education as a guide in using drugs. This has the potential to cause problems in the health sector. The method of activity is based on the health promotion model, through providing education and training for selected cadres about the rational use of drugs. This activity involved PKK women in Candi 3 hamlet, Sardonoharjo Village, Sleman. The results of the activity showed an increase in knowledge of PKK women in Candi 3 hamlet and the formation of snowball cadres that would help the community to use drugs appropriately and rationally.
\end{abstract}

Keywords: Pharmacist, self-medication

\section{PENDAHULUAN}

Kesehatan adalah kunci produktifitas dan pembangunan suatu bangsa, menciptakan masyarakat sehat dan sadar akan prinsip penggunaan obat untuk mengatasi masalah kesehatannya adalah salah satu upaya menggerakkan masyarakat untuk hidup sehat (Kemenkes RI, 2015). Perilaku pencarian pertolongan kesehatan yang utama atau paling banyak dilakukan jika penduduk sakit adalah melakukan pengobatan mandiri / swa medikasi (self medication) dengan membeli obat di warung, toko swalayan dan apotek. Perilaku ini dipandang positif jika penduduk sudah memiliki panduan atau rujukan dalam penggunaan obat yang benar (Glanz et al, 2008). Hasil penelitian di Kecamatan Depok dan Cangkringan menunjukkan bahwa ada 87,73 \% warga melakukan swa medikasi, dari 174 responden ada 118 (67,8\%) melakukan swamedikasi secara tidak rasional. Hal ini 
menunjukkan bahwa masih banyak masyarakat belum mengetahui penggunaan obat secara rasional (Kristina dkk, 2008).

Data yang diperoleh dari ketua RT belum ada sistem/sosialisasi terkait penggunaan obat yang benar bagi warganya. Masyarakat hanya mengandalkan iklan, referensi keluarga, tetangga yang tidak memiliki dasar pendidikan kefarmasian sebagai panduan dalam menggunakan obat. Hal tersebut potensial menimbulkan permasalahan di bidang kesehatan, sejalan dengan data yang dikeluarkan Kementrian Kesehatan Republik Indonesia melalui RISKESDAS (Riset Kesehatan Dasar) tahun 2013 teridentifikasi banyaknya kesalahan masyrakat (rumah tangga) dalam menggunakan obat yang membawa risiko keberlanjutan penyakit.

Warga masyarakat membutuhkan semacam system pendidikan penggunaan obat yang benar dan lengkap dengan metode dan media untuk menyampaikan pesan-pesan penggunaan obat yang benar untuk meningkatkan pengetahuan dan keterampilan warganya dalam menggunakan obat. Dinas kesehatan Kabupaten Sleman melalui Puskesmas Ngaglik dengan wilayah kerja Desa Sardonoharjo, dusun Candi 3, termasuk RT 1 dan Rt 2, RW 5 juga belum pernah mencipta kader atau sistem dalam rangka mengatasi permasalahan tersebut. Hal ini mendorong Prodi Farmasi Universitas Islam Indonesia untuk melaksanakan kegiatan Pengabdian kepada Masyarakat (Pengabmas) berupa pemberian edukasi tentang penggunaan obat yang benar karena sebagai institusi peruguran tinggi farmasi tempat para Apoteker dididik sebagai sarana karya, aplikasi ilmu dan teknologi serta memberikan kemanfaatan bagi masyarakat. Hal ini juga sebagai bentuk dukungan terhadap program pemerintah di bidang kesehatan dan perwujudan Tri Dharma Perguruan Tinggi.

\section{METODE}

Metode pelaksanaan program ini terdiri atas 6 tahapan, yaitu :

1. Pra Kegiatan

Di tahap ini dilakukan rekruitmen tim yang terdiri dari relawan mahasiswa yang bersedia sebagai bagian dari tim survey, pelaksana teknis kegiatan dan pendamping kader/masyarakat.

2. Community Analysis

Tim dan relawan melakukan identifikasi dengan menggunakan kuesioner dan mengunjungi setiap keluarga untuk menanyakan terkait prilaku dalam menggunakan obat dan pertanyaanpertanyaan (pre-test) seputar penggunaan obat yang benar..

\section{Targeted Assessment}

a) Tim melakukan identifikasi kelompok ibu-ibu potensial sebagai kelompok sasaran untuk penerapan program ini dikarenakan adanya struktur pertemuan rutin desawisma/PKK sehingga sesuai jika kelompok ibu-ibu menjadi ujung tombak kelompok mitra. 
b) Ibu-ibu diminta untuk mengisi kuesioner untuk mengukur tingkat pengetahuan dan diskusi

c) untuk mengetahui prilaku harian dalam menggunakan obat.

\section{Program Plan Development}

a) Membuat materi presentasi untuk disampaikan ke masyarakat tentang penggunaan obat yang benar

b) Membuat modul sebagai pedoman penggunaan obat yang benar

c) Membuat poster dengan pesan-pesan penggunaan obat yang benar yang bias ditempel ditempat umum ataupun rumah-rumah warga.

\section{Implementation}

a) Mengundang ibu-ibu untuk sosialisasi program

b) Ibu-ibu diminta kembali mengisi kuisioner tentang pengetahuan penggunaan obat yang benar.

c) Ibu-ibu yang memiliki skor tertinggi, ditawarkan untuk menjadi kader bola salju.

d) Memberi pelatihan kader bola salju

e) Bersama kader bola salju dan mahasiswa pendukung memberikan informasi, pelatihan keterampilan ke masyarakat tentang penggunaan obat yang benar.

\section{Evaluation}

Pada kegiatan ini tim melakukan evaluasi terhadap proses (saat program berlangsung) melalui dokumentasi jalannya kegiatan, mencatat hambatan dan solusi ketika program berjalan.

\section{HASIL DAN PEMBAHASAN}

Kegiatan pengabdian masyarakat pada ibu-ibu PKK di Dusun Candi 3, RT 1 dan 2 berjalan dengan lancar. Warga menunjukkan antusiasme yang baik sepanjang pelaksanaan kegiatan ini, namun sayangnya tidak semua warga dapat berpartisipasi pada kegiatan pengabdian masyarakat ini. Hal ini terkait waktu pelaksanaan yang bertepatan dengan aktivitas warga yang lain seperti bekerja, dan beberapa warga menolak untuk hadir dengan alasan kesibukan. Dalam kegiatan ini, ada 2 kegiatan utama yaitu pemberian edukasi tentang obat dan swamedikasi, serta pembentukan kader bola salju. Edukasi diberikan dengan metode ceramah, tanya jawab, diskusi, dan simulasi. Materi edukasi mengacu pada materi GEMA CERMAT yang diterbitkan oleh Kementrian Kesehatan RI sedangkan media edukasi yang digunakan berupa leaflet, benner dan materi langsung dari pemateri. Edukasi disampaikan oleh apoteker dari beberapa apotek di wilayah Candi 3 dan perwakilan apoteker dari program Gema Cermat. Hal ini bertujuan untuk menciptakan lingkungan yang saling mendukung 
dengan optimalisasi peran apotek dan apoteker di sekitar masyarakat guna mendampingi masyarakat dalam penggunaan obat dengan benar.

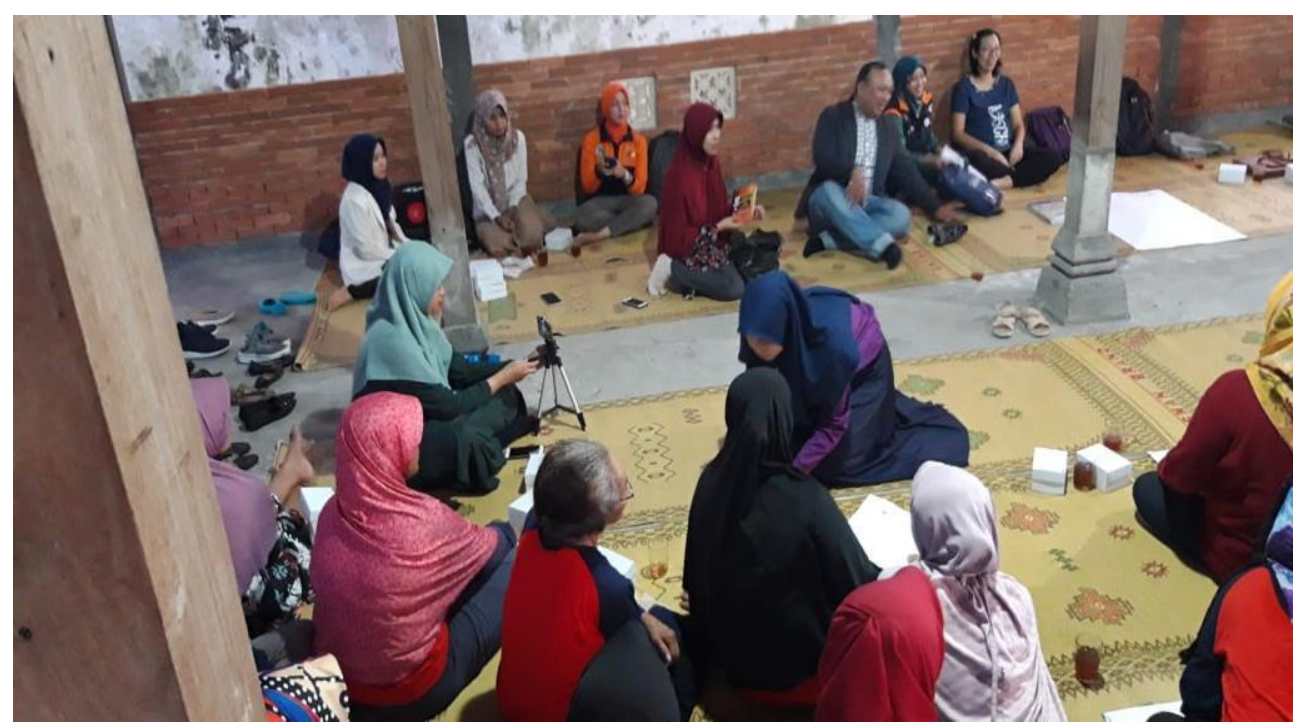

Gambar 1. Pemberian Edukasi

Pengukuran efektifitas keberhasilan kegiatan edukasi dilakukan dengan menggunakan pretest dan posttest. Pretest dilakukan dengan membagikan kuesioner untuk diisi oleh peserta sebelum dilakukan edukasi, sedangkan posttest dilakukan setelah penyampaian edukasi berakhir.

Kuesioner berisikan 15 pertanyaan dalam bentuk pernyataan benar dan salah. Berdasarkan hasil yang diperoleh, terdapat perubahan nilai rata-rata dari yang sebelumnya 63,4 pada pretest menjadi 90,7 pada pengujian posttest, seperti yang disajikan pada gambar 1. Peningkatan nilai rata-rata ini menunjukkan bahwa edukasi yang diberikan mampu meningkatkan pengetahuan masyarakat. Selanjutnya, peserta dengan skor tertinggi dalam menjawab kuesioner pengetahuan, dan aktif dalam kegiatan pengabdian masyarakat ini dipilih sebagai kader bola salju.

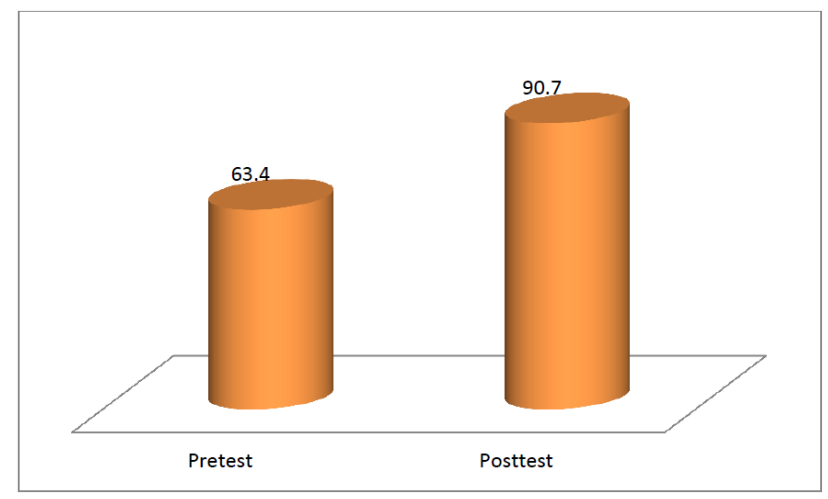

Gambar 2. Grafik Hasil Pengisian Kuesioner Tingkat Pengetahuan 
Febrianti $^{1 *}$, Yulianto $^{1}$, Saepudin $^{1}$, Lusiana $^{2}$

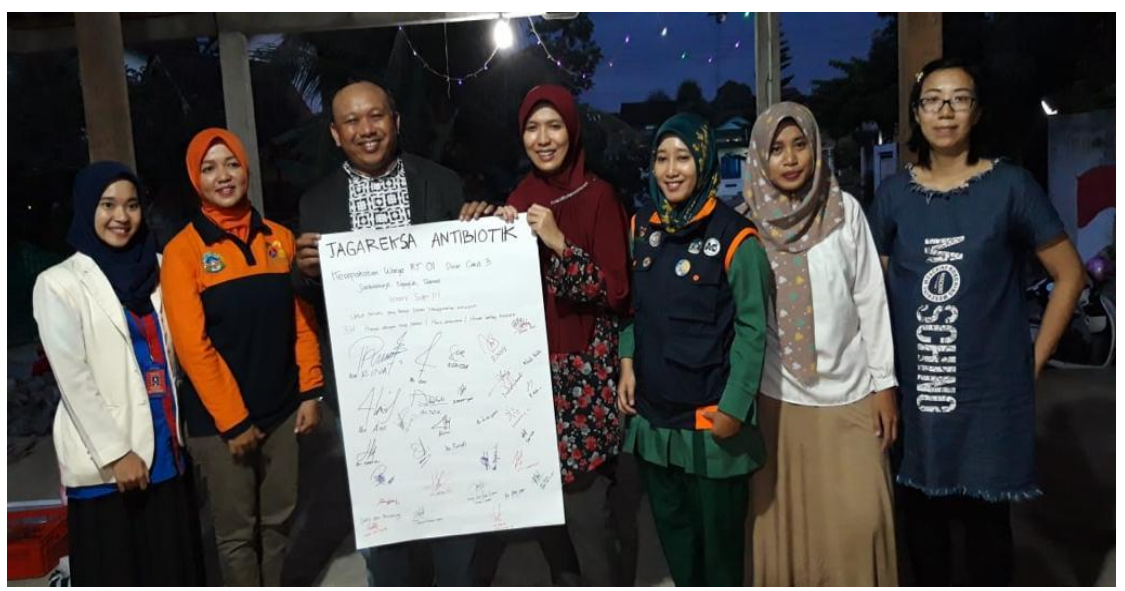

Gambar 2. Pemilihan dan Pembuatan Komitmen Bersama dengan para Kader.

Dalam kegiatan ini terpilih 2 masyarakat sebagi kader bola salju. Kader terpilih selajutnya diberikan pelatihan oleh para apoteker di wilayah dusun Candi. Keberadaan kader ini sangat penting karena kader dianggap menjadi ujung tombak dalam melakukan pergerakan masyarakat. Masyarakat akan lebih mudah digerakan dan cenderung mengikuti arahan yang diberikan kader karena kader bagian dari masyarakat.

\section{SIMPULAN}

Program pengabdian masyarakat telah terlaksana dengan baik, terbukti adanya peningkatan pengetahuan masyarakat tentang penggunaan obat secara tepat. Ibu-ibu PKK terlibat aktif dalam setiap kegiatan pengabdian. Dari kegiatan ini terpilih 2 ibu sebagai kader bola salju yang diharapkan dapat menjadi kader kesehatan di wilayah Candi 3, desa Sardonoharjo, Sleman, Yogyakarta. Kegiatan selanjutnya yang terpenting adalah upaya untuk meningkatkan dan mempertahankan kinerja kader. Kader perlu terus dijaga motivasi dan kemampuannya.

\section{UCAPAN TERIMAKASIH}

Kepada Kepala Desa Sardonoharjo dan seluruh aparat desa serta ketua RT 01 dan 02, Dusun Candi 3 dan seluruh warga Candi 3, atas bantuan dan ijin dalam pelaksanaan kegiatan pengabdian masyarakat. Direktorat Penelitian dan Pengabdian (DPPM) Universitas Islam Indonesia atas pemberian hibah Pengabdian Masyarakat tahun 2018.

\section{DAFTAR PUSTAKA}

Glanz, K., Rimmer, B.K.,and VIswanath, K. 2008. Health Behavior and Health Education, Theory, Research and Practice. 4edition John Wiley \& Sons. USA.

Kementrian Kesehatan RI, 2013. Hasil Riset Kesehatan Dasar: RISKESDAS 2013. 
Kementrian Kesehatan RI. 2015. Gerakan Masyarakat Cerdas Menggunakan Obat: Keputusan Menteri Kesehatan Republik Indonesia No HK.02.02/MENKES?427/2015. Jakarta.

Kristina, S.A., Prabandari, Y.S., Sujaswadi, R. 2008. Prilaku Pengobatan Sendiri yang Rasional pada Masyarakat Kecamatan Depak dan Cangkringan Kabupaten Sleman. Majalah Farmasi Indonesia No. 19 (1). 